Con mis goggles baratos

alcanzamos a ver todo el abismo:

valles, grutas, corales laberintos,

peces que rozan las piernas de Laura

y el claro que resalta los ojos de Sofía.

¿En el fondo de todo habrá fogatas?,

¿el cenote es el cielo del abismo

y un eclipse es el fondo del cenote?

Nunca tan alto caí:

somos los turistas en el agua

como los turistas que somos en el tiempo.

Llueve, pero solo arriba.

\title{
LO QUE SEA MENOS "BONSÁI"
}

\section{Sangre}

Lúgubre y líquida

flor de Jamaica

que dibuja la vida.

\section{Los cerros}

Barcos de vela verde

navegan frente al sol:

se pierden.

\section{Recuerdo de Facebook}

El amor reconoce

la exacta duración de una burbuja.

\section{Gran Turismo}

Un Xbox empolvado.

Se oye una moto GP

en la autopista. 


\section{Coincidencia}

Le cortan la cabeza a una gallina:

su sombra no se mueve.

\section{Calle 12 de diciembre}

La máquina de la tortillería

parece que llora todo el tiempo,

no deja de sacar los círculos de masa

y un tráiler atropella a un perro anónimo.

\section{Heredad}

Encontraron Atlantis:

navegaron las islas de botellas de plástico

y fundaron un nuevo y único continente. 